\title{
Accreditation of Academic Programmes and University Administration in Public Universities in South West Nigeria
}

\author{
Comfort Olufunke Akomolafe, Veronica Olubunmi Adesua \\ Department of Educational Management \\ Faculty of Education \\ Ekiti State University \\ Ekiti State, Nigeria
}

\begin{abstract}
.
The study examined Accreditation of Academic Programmes and University Administration. Descriptive Research design was adopted for the study. The population of the study comprises academic staff in public Universities in Southwest Nigeria. The sample of the study comprises three hundred and fifty-one (351) respondents. Purposive Sampling technique was used to select academic staff holding administrative positions as Heads of Department and Directors of Programmes. A research instrument titled "Impact of Accreditation on University Administration" (IAUA) was administered to elicit information from respondents. Two Research Questions were formulated while two Research Hypothesis were tested at 0.05 level of significance. The study revealed that the level of administrative effectiveness was moderate, also the status of accreditation was full. There is a significant relationship between accreditation of Academic Programmes and administrative experience. Also, there is a significant difference in the perception of the impact of accreditation based on administrative experience. Based on the findings of the study the researcher recommended that university administrators should ensure that accreditation of academic programmes takes place regularly within the university system to ensure quality programmes in the Universities. Academic staff with wide length of experience should be included in the accreditation team. Also, management should respond promptly to accreditation criteria and make funds readily available to improve learning facilities in the Universities.
\end{abstract}

\section{Introduction}

Universities are established to impart knowledge and develop different kinds of skills to enable students to be productive, earn a living and contribute towards national development. The University system therefore is saddled with three major responsibilities namely Teaching Research and Community Services. It is pertinent to note that quality is of utmost importance for University
Education. The duties of University Administrators therefore are to ensure Quality Assurance through the accreditation process. Accreditation is a process that is designed to determine whether Universities meet the Minimum Academic Standard (MAS) and whether Universities achieve its mission and stated objectives. [1] described accreditation as the systematic review of education programmes to ensure that acceptable standards of education, scholarship and infrastructure are maintained. Accreditation is a process that aids University institution to develop and sustain effective educational programmes and assure the educational community, academic programmes on acceptable minimum standard provided and outlined by the National Universities Commission [2].

Administration is the application of principles, policies, procedures, rules and regulations to achieve organizational goals. [3] defined administration as the ability to mobilize people, procedures and materials to achieve desired results. Administration is a universal concept that cuts across any organization, whether military, business, public service, school or government. [4] defined administration as the implementation or execution or actualization or effectuation of what plan that has been put in place. Educational Administration on the other hand, is therefore the arrangement of the human (teaching and non-teaching) and material (school plant, equipment, funds, constraints) resources and programmes available for Education and using them systematically to achieve educational objectives.

University Administration involves the administration of education at the University level. University administration can be illustrated through a simple organ. The legal structure, administrative structure, formation and mode of operations of University in Nigeria differ depending on whether it is a Federal, State or Private owned Universities. However, despite the differences there are many similar areas in which university run their affairs.

[5] and [6] explained that many Universities in Nigeria function through administrative structure, officers, bodies or levels, this include the Visitor, the Chancellor, Senate, Faculty and Academic department. In Nigeria, the Visitor is usually the 
head of government, in other words, the President in the case of Federal University and Governor in case of State Universities, he usually comes to grace convocation ceremonies and address the academic communities on matters of the moment [7].

The second administrative structure of the University is the Chancellor. [5] explained that Chancellors are political appointees of the government who act as ceremonial heads in Universities. At the Apex of the administrative structure within the university is the Governing Council headed by the Chairman. The governing council of each tertiary institution has the power under the law to govern the university. It is charged with administrative functions such as goal setting, policy, formulation, staff development, general discipline, budget approval and license activities with the government.

The head of the university is the vicechancellor. The highest academic body is the Senate headed by the vice chancellor while the Registrar is the secretary. The Senate regulates academic activities of the university based on guidelines provided by the National Universities Commission (NUC). [5] explained that the Senate is responsible for development of Academic Programmes, control activities relating to teaching and promotion of research, examination, award of degrees and certificates, admission and discipline of students. The Faculties and Academic departments are units where academic activities take place. They are created by law to facilitate the employment of specialized academic personnel and co-ordinate their activities based on their area of subject specialization or discipline.

The objectives of accreditation of University Academic Programmes according to the National Universities Commission. [2] include the following:

- To ensure that at least the minimum academic standard documents are attained maintained and enhanced.

- To assure that employers and other members of the community that Nigerian graduates of all academic programmes have attained an acceptable level of competency in their areas of specialization.

- To certify to the international community that programmes offered in Nigerian Universities are of high standard and their graduates are adequate for employment and for further studies.

The history and historical development of academic programmes in Universities in Nigeria can be traced to the year 1990, when the first accreditation exercise was embarked upon, since then, since then accreditation exercise became a continuous exercise, the National Universities Commission (NUC) had carried out series of serious accreditation exercise to ensure that the provision of the benchmark for the minimum academic standard is strictly followed. Thus, accreditation exercise has become a mechanism, yard stick and indicator to ensure quality assurance and the benchmark for (BMAS) minimum academic standard in Universities in Nigeria [2] and [8].

According to [9] there are three types of Accreditation, namely Interim and Denied Accreditation. Full Accreditation is granted to programmes that satisfy the provision of the Minimum Academic Standard (MAS) for a period of five academic sessions. The programme attains minimum of $70 \%$ aggregate score as well as four core areas of academic content, staffing, physical facilities/library. Interim accreditation is granted to programme that have minor deficiency that must be rectified within a stipulated time/period. The programme must also attain an aggregate score of not less than $60 \%$. Programmes with a total score above $70 \%$ but less than $70 \%$ in any of the indicated four core areas is awarded Interim status which could be valued for a period of not more than two academic sessions. Denied accreditation is granted to any academic programme which has failed to satisfy the minimum academic standard. It is applied to programmes with less than $60 \%$ aggregate score. The re-visitation can be carried out under the University concerned. The University stops admitting student into such programme with effect from the next admission exercise.

[10] in a study carried out on Accreditation outcomes, quality of and access to University Education in Nigeria found out that full accreditation status was found to have increased from 12.6 in 1999 to 48.30 in 2005, interim accreditation reduced from 72.66 in 1999 to 48.30 in 2005. They findings also revealed that Federal Universities had more programmes with full accreditation and less programmes with denied accreditation. State Universities had less number of programmes with full accreditation status. The findings finally revealed that accreditation status of most Academic programmes improved in subsequent accreditation exercises which means that the programmes deficiencies were remedied. Moreover, the programmes that were denied caused or led to reduction in the number of vacancies for student admission. It was recommended that the Academic programme in Universities in Nigeria should be monitored to scale through accreditation hurdle. It was concluded that accreditation programmes help to improve quality of University Education.

[11] in his studies titled NUC's Sham Accreditation revealed that some of the processes that leads to the awards of degrees are of no interest to the accreditation officers and that there were sharp practices in the competition of degree results in some Universities. [12] reiterated that Universities (administrators) should pay attention to the quality and quantity of academic staff while [13] however 
reported disparities in the ratio of academic staff and students in some Universities in Nigeria

In Nigeria, the Part-Time programme accreditation division is headed by Engineer. Abraham Chundusu. The Division is divided into three (3) namely Federal Universities Accreditation Unit, State Universities Accreditation Unit and Private Universities Accreditation Unit. The Division was created on July 23, 2014 to handle Accreditation of degree programmes in Affiliate Institutions.

The instruments used for accreditation of Affiliate Institutions include the following:

- Manual for accreditation procedures for Academic programmes in Nigerian Universities.

- Self-Study Firm (NUC/SSF).

- Programme Evaluation Form (NUC/PIF).

- Accreditation Panel Report Form (NUC/APRF).

- Accreditation Re-Visitation Form (NUC/ARVF).

Function of The Affiliate Institutions Division.

- Coordinating the accreditation of Full and Part-Time programmes in Affiliate Institutions.

- Obtaining the list of Approved programmes from the Department of Academic Standard to determine the list of Programmes ready for accreditation.

- Preparing the monthly and annual reports on activities of the Division.

- Responding to enquiries and advising NUC on issues relating to Accreditation of Academic programmes in Affiliate Institutions.

[6] viewed the management of University Education from two dimensions, the external and the internal levels. The external level is controlled by the Federal Government through the National Universities Commission (NUC), a body charged with the coordination of University administration in the country while the internal level of management of each University is represented by a simple organ. These include the visitor, usually the president for federal universities and Governor for state university that establishes it, the Chancellor, who is the titular head that presides at all meetings of Convocations held for conferring degrees. At the apex of the management structure within the University is the Governing Council, headed by the Chairman (ProChancellor) which is charged with Administrative functions such as goal setting, policy formulation, staff development, general discipline, budget approval and liaison activities with the government. Next is the Senate, headed by the Vice-Chancellor and the Registrar as the secretary. The academic activities of the University are being regulated by the Senate following the guidelines by the NUC.
[9] posited that the activities of National Universities Commission (NUC) involves improving the Quality of University Education in the country. While Mgbekem in [6] claimed that Universities Administration in Nigeria are carried out through committee system which are directly responsible to the council or the Senate. These committees include:

- Finance and General Purpose Committee

- Development Committee

- Appointments and Promotion Committee

- Admissions Committee

- Academic Committee

- Committee of Deans

- Research Grant Committee

- Ceremonies Committee.

[14] explained that the main objectives of NUC is to ensure the orderly development of University Education in Nigeria, maintain its high standard and ensure its adequate funding. In support of this, [6] explained that one of the areas where University management (administrators) need to identity and embark upon certain transformational change is the area of accreditation of academic programmes.

[1], in his study revealed that the quality of accredited programmes depends on the level of funding of Universities in Nigeria. Also the quality of programme accreditation and physical facilities of Universities in Nigeria have high relationship furthermore, programme accreditation is positively related to staffing in Nigerian Universities, based on his findings it was however recommended that Universities (academic) administrators should be involved in the accreditation team to ensure quality programmes in the Universities. The findings of this study corroborates that of [14] that there is a significant relationship between accreditation and resource input into Nigerian Universities, quality of output, quality of process, based on their findings it was recommended that accreditation exercises and conducts should be properly manipulated and supervised without playing politics to achieve education standards, quality and effectiveness for the purpose of accomplishing the goals of University Education in Nigeria.

[6] in their study revealed that the University system had continued to score more points as a result of newly accredited courses in various faculties by the National Universities Commission (NUC). This is a giant stride and a remarkable achievement by the University Administration of Ekiti State University (EKSU). This may be as a result of the University Administration, responding urgently to accreditation criteria, making funds available to improve learning facilities, upgrading infrastructure to meet the accreditation criteria, employing more staff to meet 
up personnel criteria, managing staff through supervision, ensuring that records are kept to ensure information for accreditation, improve handling of records, improve provision of library facilities and ensure that lecture theatre is improved. In the same vein.

The National Universities Commission instrument for Institutional Accreditation indicates that Institutional Accreditation is conducted based on a set of minimum academic standards, such standards have been set based on the following criteria and standard:

- Institutional vision, mission and strategic goals.

- Institutional Governance and Administration.

- Institutional Resources.

- Quality of the Teaching, Learning and Research.

- Institutional Efficiency and Effectiveness.

- Extension Services and Consultancies.

- Transparency, Financial Management and Stability.

- General Ethos.[16]

It is pertinent to note that members of an Institutional Accreditation Team are expected to measure objectively the performance of the University against the minimum standard. The aim and expectations of the National Universities Commission (NUC) in the Accreditation exercise is to further enhanced Quality in the Nigerian University System.

The National Universities Commission (NUC) designed an institutional pilot study for Universities in Nigeria to provide database/information about the status of the Universities and then grade accordingly based on the quality of the academic programme and the status of the university. This Institutional Pilot study instrument is divided into sections. The first section, that is Section A comprises the following:

- Name of the University. This refers to the Name of the university visited for Accreditation exercise.

- Location Address: The state the University is situated.

- Web Address: The website of the university.

- Year Established: The Year the university was founded /established

- Total Enrollment of the Undergraduates students and the Postgraduates in Universities the university for the accreditation exercise.

- Officers of the University; The Name, Email Address and Telephone of the following Principal officers of the University are required, they include: The Chancellor, Pro-Chancellor, Vice Chancellor, Deputy Vice Chancellor(s), Registrar, Bursar and the University Librarian [16]
The second section, that is, Section B is required to provide information (data) about the strength and weakness of the University based on standards and recommendation for improvement. These Standards are based on the following areas:

- Vision, mission and strategic goals of the University in relation to institutional responsiveness to local, national and international development agenda.

- Overall University curriculum meeting labour market, knowledge or other sociocultural needs.

- Quality of institutional Governance and Administration by Council, Senate, Principal Officers (Vice Chancellor, Registry, Bursar, University Librarian, Faculty Boards, Departments and other statutory bodies in relation to the vision, mission and strategic goals of the University.

- Effectiveness of the Committee System.

- Quality and quantity of Institutional resources such as Academic infrastructure and facilities (classrooms, laboratories, workshops, library and staff offices) facilities for sports games and recreation, ICT and healthcare facilities.

- Quality of teaching, Learning and Research such as curriculum delivery, e-learning and use of new technologies for teaching, learning and research ethics, codes and conduct.

- Institutional Efficiency and Effectiveness such as Students admission, selection process, registration for courses, issuance of transcripts and certificates, recruitment process, internal and external efficiency of the system, timely release of results, staff recruitment process, staff mix, staff welfare in line National Universities Council (NUC) Guidelines.

- Turnout rate of mails in the offices of Principal Officer.

- Extension, Relationships with internal and external constituencies and consultancy such as international organizations.

- Transparency, Funds Generation, Financial Management and Stability such as Funds management, external auditors reports and published Annual reports.

- General Ethos such as Staff and Students discipline [16]. This section concludes and ends with comments by the Vice-Chancellor, with Name and Signature of the Vice-Chancellor with the Name and Signature of the Accreditation Team Leader.

The Accreditation Pilot Study has a section which should not be made available to the University and the University Administrators (that is the Section C) this is confidential and is meant only to be completed by the University Accreditation Team. This section contains the overall grade which consists of columns for the following: 
The Score, the Letter Grade, the Judgment and Remarks. The score ranges from $40 \%$ to $80 \%$, and above, the Letter Grade is A-F, while the judgment is written based on the following statements, for example, this may be written as Full Accreditation usually for 8 year life span. Interim Accreditation usually for 3-5 year life span and Probation for 1-2 year life span. The remarks are written in the following order; Excellent or Good for Full Accreditation depending on the Letter Grade/Score, Fair for Interim, Poor for Probation and Fair for Denied Accreditation [16].

The National Universities Commission (NUC) Programme Evaluation Form, otherwise known as the NUC/PER is a confidential Report Form which is designed by the National Universities Commission (NUC) to be completed by each member of the Accreditation panel, the information /report that is contained in the form is strictly confidential and is strictly for the official use of the National Universities Commission (NUC) and its authorized agents. It also contains the Name and signature of the Assessor. (that is the National University Commission (NUC) Accreditor).

The relevant sections of the programme evaluation form are to be completed by scoring with comments written based on the curriculum, the physical facilities, books, journals, staff and so on. The form is completed and presented in the form of a statement of facts report, the report is discussed with the Vice Chancellor and his team with the panel members. This is signed, after comments and recommendations of the panel have been written on the programme to be accredited, this is handed over to the National Universities Commission (NUC) representative at the end of the Accreditation exercise for the university.

The Accreditation panel report (APRF) is duly signed by all panel members, the confidentiality of the status of the academic programme for the Accreditation is strictly maintained. The report is divided into six main components; these include the following: -

a. Academic matters:

i. The programme objective

ii. the curriculum

iii. Admission requirements

iv. Admission Regulations

v. Standard of Tests and Examinations

vi. Evaluation of Students' work

vii. Degree Projects/Practical Work

viii. Students Course Evaluation

ix. Evaluation of Skills Acquisition

x. External Examiners System

xi. Internal Quality Assurance

b. Staffing.

i Non-Teaching Staff

ii. Head of Sub-Discipline

iii. Staff Development

c. Physical Facilities i. Facilities per Student / Equipment

ii. Classroom facilities and Equipment

iii. Safety and Environmental Sanitation

d. Library - Books, Journals and other

Resource materials for the Programme including e-learning facilities

e. Funding - Financing of programmes by the university

f. Research and Collaborations

g. Tracer System and Employers' Rating of

Graduate in Practical Work and Degree

Project [17]

The Programme Philosophy objectives usually state the type of Graduate the Programme is designed for and the knowledge and skills the Graduate of the Programme should be able to perform in relation to the Philosophy, goals and objectives of the Institution. This is assessed according to the Minimum Academic Standard laid down for the Programme.

It is pertinent to note that the curriculum for degree Programme should give the student total education that would make them equipped with the Knowledge and Professional Skills. To practice his or her chosen field at the appropriate level. The curriculum and structure of a university should be assessed based on the stipulations in the benchmark Minimum Academic standard. This is designed in line with core compulsory courses, scores are awarded to indicate remedies to improve the curriculum content and the structure of the Philosophy and objectives of the academic programme. Also is innovation, scores are awarded for inclusion of innovative courses in the curriculum. Scores are awarded for adequate content coverage [17].

Admission requirements of students into Programmes is expected to meet the National Universities Commission (NUC) Benchmark Minimum Academic requirements for Admission. Names of Students who do not meet the admission requirements of Five (5) O 'level credits in relevant subjects as prescribed by NUC and JAMB are regarded as deficiencies and these are stated against each name and state in relation to the layer down standard for the Programme.

Scores are awarded for provision of Academic Regulations for students in form of handbooks, these include rules and regulations guiding conduct of semester and final examinations grading system, penalties for examination malpractices, requirements for graduation and so on. It is also expected that standardized test and examination are carried out for a Programme which are relevant to the curriculum based on past examinations, test and continuous assessment. Examinations for the past three years relevant to the syllabus and the quality of students answer script are awarded scores, these may help to improve students' performance [17] 
Evaluation of students' work is very important in teaching and learning process which are assessed by panel members of the National Universities Commission (NUC). Marking Schemes and grading of projects, continuous assessment, Coursework and examination are expected to be consistent. Panel members comment on clarity and adequacy and make recommendations and suggestions for improvement if necessary. To meet the quality of manpower produced for a Programme, all degree Programmes must include all degree projects, this is to meet the level of competency and training for the chosen field or discipline of students [17]. The quality depth and scope of practical work conducted are also measured through citing of samples, design, law books, manuals and so on to ascertain the adequacy of the level of skill of students and correct deficiencies where necessary. The panel members of the National Universities Commission (NUC) ascertain the adequacy of the course content learning materials, course delivery and critical facilities. National Universities Commission (NUC) Accreditation panel members also ascertain the level of skill requirements. National Universities Commission (NUC) also ascertain the quality of the external examiners report vis-à-vis the standard of work and instruction and insuring if it meets the national standard layer down for the level of satisfaction [17]. The adequacy of teaching staff is determined by National Universities Commission (NUC) based on the following:

- The staff/students ratio.

- Percentage of staff in each subject area.

- Staff mix by rank, competence.

The staff structure for academic staff are stipulated by NUC guidelines is expected to be 20:35:45 for Professors: Readers: Senior lecturer: Lecturer 1: and below respectively [17]. The qualification of Academic Staff ideally should be Ph.D. National Universities Commission (NUC) Consider the percentage of Staff with $\mathrm{Ph}$. D degree in various subjects, area or discipline. The competency of teaching staff at Lectures Tutorials, Universities and Workshops are also assessed and scored.

The administration of college, school faculty and department based on the leadership role with policies affecting staff and students is accessed based on effectiveness of academic experience and academic leadership in the area of Educational administration. The adequacy of non-teaching staff on ground to manage laboratories, library, clinics, ICT centres in their qualification are considered. The upgrading and updating of staff through staff development programmes such as conferences, workshops, seminars are confirmed. The adequacy of Physical Facilities such as laboratories, clinics, studios, farms, museums for the Programme and the professional skills necessary are checked by National Universities Commission (NUC) as stipulating the guidelines of National Universities Commission (NUC). The size, space and basic facilities in lecture theatres are ascertained to be Line with NUC standards [17]. The Adequacy and maintenance of equipment and furniture in the classroom, office accommodation for lecturers, safety and environmental sanitation of teaching facilities, library and e-library facilities and its accessibility on functionality to staff and students is also ascertained.

The funds available in financing of academic programmes for which accreditation is required is ensured. All these are indicated in the National University Self Study Form. Finally, evidence of research and collaboration by staff and students within and outside the Universities are of Paramount to the National Universities Commission (NUC) [17].

\section{Statement of the Problem}

The management of universities seems not responding urgently to accreditation criteria, it appears that funds are not readily available to improve learning facilities. Management seem not to meet up with the accreditation criteria, also some school records may not be adequately kept ensuring adequate information for accreditation, library facilities and lecture theatres seem not to be adequately ensured or provided by University administrators. Moreover, University Administrators may not adequately employ staff or adjunct lecturers to meet up with the challenges of inadequate personnel. However, it appears that some universities in Nigeria seems not to meet up with the National Universities Commission, that is the NUC's benchmark for minimum academic standard as stipulated.

\section{Purpose of study}

This study examined accreditation of Academic Programme and University Administration in Public Universities in South West Nigeria.

\section{Research Questions}

I. What is the level of administrative effectiveness of academic staff in Public Universities in South West Nigeria?

II. What is the Status of accreditation in Public Universities in Southwest Nigeria?

\section{Research Hypotheses}

I. There is no significant relationship between accreditation of Academic Programmes and Administrative experience in Public Universities in Southwest Nigeria. 
II. There is no significant difference in the perception of the impact of accreditation based on administrative experience in Southwest Nigeria.

\section{Methodology}

Descriptive Research design of the survey type was adopted for the study. This research is descriptive because it describes Accreditation of Academic Programmes and University Administration. A research instrument titled "Impact of Accreditation on University Administration" (IAUA) was administered to elicit information from respondents. The population of the study comprises all academic staff who occupy various administrative positions with administrative experience in the public Universities in Southwest, Nigeria. The sample of the study comprises three hundred and fifty-one (351) respondents. Purposive Sampling technique was used to select academic Staff who held administrative positions as Heads of Department and Directors of Programmes, since they participated in the accreditation exercises.

\section{Data Analysis and Results}

\subsection{Question 1}

What is the level of administrative effectiveness of academic staff in public universities in Southwest Nigeria?

Table 1. Level of Administrative Effectiveness

\begin{tabular}{l|l|l}
\hline $\begin{array}{l}\text { Administrative } \\
\text { Experience }\end{array}$ & Frequency & Percentage \\
\hline HOD & 310 & 88.3 \\
Director of & 41 & 11.7 \\
Programme & & \\
Total & 351 & 100.0 \\
\hline
\end{tabular}

Table 1 shows that $310(88.3 \%)$ of the total respondents; representing the majority were Heads of Departments while $41(11.7 \%)$ respondents were Directors of programmes. This implies that the level of administrative experience is moderate.

\subsection{Question 2}

What is the status of accreditation?

Table 2 presents the status of accreditation of university academic programmes. The result shows that 327 representing $93.2 \%$ of the total sample indicated 'full accreditation' of their academic programmes while 24(6.8\%) were granted interim accreditation' status.

Table 2. Status of accreditation

\begin{tabular}{l|l|l}
\hline Status of Accreditation & Frequency & Percentage \\
\hline Full & 327 & 93.2 \\
Interim & 24 & 6.8 \\
Total & 351 & 100.0 \\
& & \\
\hline
\end{tabular}

This implies that the status of accreditation was full.

\section{Hypothesis 1}

There is no significant relationship between accreditation of academic programmes and administrative experience.

Table 3. Pearson Correlation of Academic Programmes and Administrative Experience

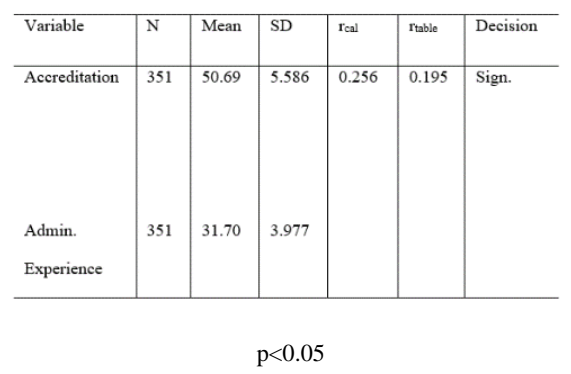

Table 3 shows that $r_{\text {cal }}(0.256)$ is greater than $r_{\text {table }}$ $(0.195)$ at 0.05 level of significance. The null hypothesis is rejected. This implies that there is significant relationship between accreditation of academic programmes and administrative experience. The relationship between accreditation of academic programmes and administrative experience is low but statistically significant in a positive direction.

\section{Hypothesis 2}

There is no significant difference in the perception of impact of accreditation based on administrative experience.

Table 4. t-test showing the perception of impact of accreditation by administrative experience

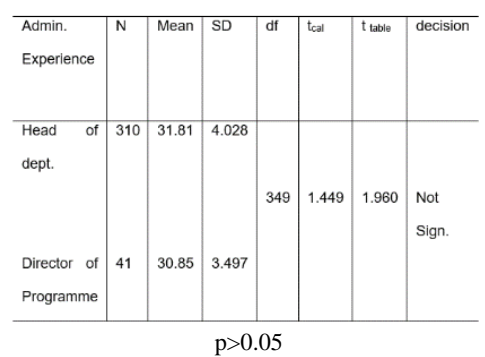


Cursory look at Table 4 shows that $\mathrm{t}_{\text {cal }}(1.449)$ is less that $t_{\text {table }}(1.960)$ at 0.05 level of significance. The null hypothesis is not rejected. This implies that there is no significant difference in the perception of impact of accreditation based on administrative experience.

\section{Discussion}

The findings of the study revealed that the level of administrative effectiveness was moderate. This perhaps was due to the fact that majority of the respondent were heads of department and directors of programmes with some level of administrative experience. This finding supports that of [8] that institutional administrators should ensure that the requirements for accreditation of academic Programmes be sufficiently provided to enhance quality.

The study also revealed that the status of accreditation was full. This perhaps was due to the fact that funds are made available to improve learning facilities, management upgrade the infrastructures to meet the accreditation criteria and improve the provision of library facilities and theatre. The findings of this study support that of [10] that accreditation status of most academic programmes improved in subsequent accreditation exercises which means that the programme deficiencies were remedied. This supports the findings of [15] that accreditation exercise has helped to improve facilities and quality assurance report which indicates the situation analysis of the universities and has invariably helped Universities to work on areas where there are challenges.

The study further revealed that there was a significant relationship between accreditation of Academic Programmes and administrative experience. This perhaps was because management must have responded promptly to accreditation criteria, ensure that school record is kept ensuring adequate information for accreditation, give room for employment of more staff to meet up criteria. This support [1] that if academic administrators are included in the accreditation team it would ensure quality programmes in the Universities, the findings of the study however contradict that of [18] that the accreditation exercise had no impact on administrative structure and efficiency of University staff.

The finding of the study also revealed that there was no significant difference in the perception of accreditation based on administrative experience. The findings support that of [6] that the University system had continued to score more points as a result of newly accredited courses in various Faculties by the National University Commission (NUC) which is as a result of the giant stride and the remarkable achievement by the University Administration. It also supports the findings of [19] that Quality assurance in the University is the ability of the institutions to meet the expectations of the users of manpower in relation to the quality of skills acquired by their outputs. To buttress this [15] claimed that this may be due to the ability of the University Administration. to meet certain criteria relating to academic matters, staff student ratio, staff mix by rank, staff development, physical facilities, funding and adequate library facilities. The findings however contradict that of [8] that there was a significant difference between lecturers and students in the perception of quality University education.

\section{Conclusion}

In conclusion the study revealed that the level of administrative experience was moderate. Also, the status of accreditation was full. Furthermore, there was significant relationship between accreditation of Academic Programmes and administrative experience. Also, there was no significant difference in the perception of the impact of accreditation based on administrative experience.

The study was able to contribute to knowledge in series of way. Regular accreditation exercise helped to remedy the deficiencies of academic programme inadequacy and help universities to meet up with the benchmark for minimum academic standard during accreditation exercises in public universities in Southwest Nigeria. University administrators help to overcome hurdles of accreditation exercise when they involve experienced academic staff with more administrative experience to participate in accreditation exercise. Certainly, accreditation helps to improve the quality of Academic programmes in public Universities in Southwest Nigeria.

\section{Recommendation}

Based on the findings of the study the researchers recommended that university administrators should ensure that internal accreditation of academic programmes takes place regularly within the university system to ensure quality programmes in the Universities. Academic staff holding administrative position with wide length of experience should be included in the accreditation team. Also, management should respond urgently to accreditation criteria and make funds readily available to improve learning facilities in the Universities.

\section{References}

[1] Anugom, F.O. (2016). Accreditation and Quality Assurance of Nigerian Universities: The Management Imperative. International Journal of Educational and Pedagogical Science. 10(a) 3187-3191.

[2] National University Commission (NUC) 2012. Manual of accreditation procedures for academic programmes 
in Nigerian Universities. Available from: www.dspace.funai.edu.ng. Accessed 20 August, 2015].

[3] Ogunsanwo, O. A. (2000). Modern Principles and Techniques of Management. Ibadan. The centre for external studies University of Ibadan. 40-43.

[4] Okunamirimi, P. O. Ibiam, N and Okunmiri, M. C. (2009). Basic Concepts in Educational Planning and Administration in J. B. Babalola and A. O. Ayeni (Eds). Educational Management: Theories and Tasks. Lagos. Macmillan Nigerian Publishers. pp. 91-92.

[5] Poopola, A (2011). Legal aspect of Education in Nigeria. Ado-Ekiti. Petoa Publishers.

[6] Adesua, V.O. and Fakunle, A.F. (2017). The Role of University Education Managers in Social Transformation: A case study of Ekiti State University. Ife Journal of Educational Studies. 16(2) 106-127.

[7] Adegbite, J. G. O. (2017). The Education Reform Agenda: Challenges for tertiary education administration in Nigeria; being a paper presented at the sixth annual seminar of the Conference of Registras of Colleges of Education in Nigeria (South West Zone) at College of Education, Ikere-Ekiti, Ekiti State.

[8] Akpan, C. P and Etor, C. R (2016). Accreditation of Academic Programmes and Quality University Education in South-south Nigeria. International Journal of Educational Studies. 13(2). 37- 54.

[9] Okojie, J.A. (2007). Higher education in Nigeria. Being a paper presented at Education in Africa Day, held at house of commons palace of Westminster, London. Retrieved from http://www.nucnigeriainfo/es\%20house ofcommons.ppt. 22 September 2017.

[10] Alani, R.A. and Ilusanya, G. (2008). Accreditation outcomes, quality of and access to University Education in Nigeria. Journal of Quality Assurance in Education. ISSN 0968-4883 16(3) 301-312. 4 October 2019.

[11] Otokunefer, T. (2015). NUC's Sham Accreditation. Avail. @ www.alphaedufoundation.org/index.php. [Accessed 7 October 2015].

[12] Bamiro, O. (2012). Dean Canvasses increased Education Funding. The Punch Newspaper. June 26.

[13] Alachenu, J. (2012). Nigerian Universities lack enough Lecturers. The Punch Newspaper. November 13. p: 43.

[14] Ibukun, W.O. (1997). Educational Management: Theory and Practice. Ado-Ekiti. Greenline Publishers

[15] Obadara, O.E and Alaka, A.A. (2013). Accreditation and Quality Assurance in Nigerian Universities. Journal of Education and Practice. 4,13-41.

[16] National Universities Commission (NUC): Instruments for Institutional Accreditation- 1. National Universities Commission. NUC.edu.ng. NUC institutional Accreditation Pilot Instrument. NUC instrum----reditation--1) 4 October2019.
[17] National Universities Commission (NUC) Revised Draft Undergraduate Accreditation. National Universities Commission Programme Evaluation form for Undergraduate Programmes. Form NUC/PEF/Revised drag....ary 4 October 2019.

[18] Oribabor, O.A. (2008). Impact of National Universities Commission (NUC) Accreditation Exercise on Universities Administrative Structure. https://waset.org>publications PDF.

[19]. Ajayi, I.A and Akindutire, I.O (2007). The unresolved issues of quality assurance in Nigerian Universities. Journal of Sociology and Education in Africa 6(1). 1-16. 